\title{
WAKTU PRAKTIK DASAR ELEKTRONIKA OTOMOTIF BAGI SISWA SMK UNTUK MENCAPAI KRITERIA KETUNTASAN MINIMAL
}

\author{
Hendri Risfandi ${ }^{1}$, Amay Suherman², Ariyano ${ }^{3}$ \\ Departemen Pendidikan Teknik Mesin \\ Universitas Pendidikan Indonesia \\ Jl. Dr. Setiabudhi No. 207 Bandung 40154 \\ cheri_hendri@yahoo.com
}

\begin{abstract}
ABSTRAK
Tujuan penelitian untuk mengetahui keperluan waktu latihan praktik dan hubungan antara pengguasaan teori dengan jumlah waktu praktik. Metode yang digunakan adalah metode eksperimen. Sampel menggunakan purposive sampling dengan pengumpulan data menggunakan tes dan observasi. Hasil penelitian menunjukan bahwa jumlah waktu latihan praktik yang ideal untuk mencapai standar waktu KKM adalah tiga kali latihan praktik, dimana pencapaian standar waktu KKM berbanding lurus dengan jumlah waktu latihan praktik. Hubungan antara pengguasaan teori dan jumlah waktu praktik menunjukan hubungan tinggi dan berbanding lurus. Kesimpulan penelitian yaitu perlu adanya penambahan jumlah jam atau penambahan alat praktik serta peningkatan pengguasaan teori siswa sebelum praktik.
\end{abstract}

Kata kunci: waktu, elektronika, otomotif, kriteria

\section{PENDAHULUAN}

Pendidikan Kejuruan merupakan pendidikan menengah yang mempersiapkan peserta didik terutama untuk bekerja pada bidang tertentu. SMK dikatakan berhasil jika siswa-siswi lulusan sekolah tersebut diserap oleh dunia industri sesuai dengan departemen mereka masing-masing. Salah satu SMK yang berusaha menciptakan tenaga kerja yang berkopetensi adalah SMK Negeri 6 Bandung. SMK Negeri 6 Bandung dalam usaha meningkatkan kualitas lulusan yang kompeten, sehingga bekerja sama dengan Toyota. Salah satu kompetensi kejuruan program studi keahlian teknik otomotif kompetensi keahlian teknik kendaraan ringan adalah dasar-dasar elektronika otomotif. Kompetensi dasar-dasar elektronika otomotif merupakan kompetensi yang diberikan oleh dunia kerja, yaitu perusahaan Toyota (Depdiknas, 2008). Toyota technical education program mewajibkan siswa memiliki kompetensi dasardasar elektronika otomotif.

Dasar-dasar elektronika otomotif merupakan pembelajaran dasar yang harus dimiliki siswa sebagai fondasi awal untuk kompetensi produktif listrik yang akan didapat di kelas XI dan XII. Siswa akan mengalami kesulitan ketika melanjutkan ke kompetensi produktif listrik

\footnotetext{
${ }^{1}$ Mahasiswa Departemen Pendidikan Teknik Mesin FPTK UPI

2 Dosen Departemen Pendidikan Teknik Mesin FPTK UPI

${ }^{3}$ Dosen Departemen Pendidikan Teknik Mesin FPTK UPI
} 
jika kompetensi dasar-dasar elektronika otomotif tidak menguasainya. Pembelajaran kompetensi dasar-dasar elektronika otomotif yang ditetapkan oleh kurikulum SMK Negeri 6 Bandung terdiri dari pembelajaran teori dan praktik. Toyota selaku patner SMK Negeri 6 Bandung memberikan fasilitas praktik berupa breadboard (papan percobaan) dasar-dasar elektronika otomotif. Breadboard untuk praktik selama ini hanya ada 1 alat dan waktu pembelajaran dasar-dasar elektronika otomotif yang ditetapkan oleh kurikulum adalah 24 jam pelajaran dengan satu jam pelajarannya selama 45 menit. Pembagian 24 jam pelajaran antara teori dan praktik, dimana teori 8 jam dan praktik 16 jam (Uno 2012).

Materi tentang pembelajaran dasar-dasar elektronika otomotif dengan waktu 24 jam pelajaran antara lain, rangkaian transistor, rangkaian resistor, rangkaian dioda dan rangkaian kondensator. Materi-materi tersebut oleh toyota dibentuk berupa jobsheet (unjuk kerja). Selama ini, empat jobsheet tersebut dilaksanakan pada satu kali latihan praktik (Sa'ud, 2009). Siswa dibagi berkelompok karena keterbatasan jumlah alat praktik dasar-dasar elektronika otomotif yang hanya terdapat satu unit. Setiap kelompok melakukan praktik dalam waktu dua jam pelajaran, dimana satu jamnya 45 menit. Jumlah siswa dalam satu kelompok terdiri dari 6-7 siswa. Waktu rata-rata setiap siswa untuk latihan jika kelompoknya tediri dari enam orang adalah 15 menit, sedangkan jika kelompoknya terdiri dari tujuh orang adalah 13 menit. Waktu latihan tersebut betujuan untuk melatih siswa

mengerjakan empat jobsheet dalam waktu 15 menit pada saat ujian, sesuai dengan standar waktu yang ditetapkan. Sewajarnya waktu praktik 13 sampai 15 menit siswa dapat menguasai jobsheet-jobsheet dasar-dasar elektronika otomotif. Kenyataannya terdapat permasalahan dalam pencapaian KKM pada kompetensi dasar-dasar elektronika otomotif. Oleh karena itu, tujuan penelitian ini yaitu untuk mengetahui keperluan waktu praktik dasar-dasar elektronika otomotif yang diperlukan untuk mencapai standar waktu KKM dan mengetahui hubungan antara pengguasaan teori dengan jumlah waktu praktik untuk mencapai KKM (Sudarmanto, 2009).

Waktu praktik sangat penting untuk mencapai KKM dalam pembelajaran, karena dengan memiliki waktu praktik yang banyak kemampuan yang dimiliki dapat bertambah karena terus diasah. Pekerjaan dapat dikerjakan dengan waktu yang cepat dan memiliki hasil yang baik. Keperluan maksudnya adalah suatu hal yang perlu ada bagi manusia untuk terus hidup. Sekiranya keperluan ini tidak dipenuhi, manusia akan mati. Oleh karena itu, keperluan waktu praktik adalah suatu hal yang di diperlukan bagi siswa untuk mengerjakan setiap pekerjaan, jika keperluan waktu praktiknya tidak terpenuhi, maka pencapaian KKM dalam 
pembelajaran akan sulit tercapai. Faktor yang mempengaruhi ketercapaian KKM salah satunya adalah jumlah waktu latihan praktik. Jika, semakin banyak mengulang-ulang, maka keterampilan semakin bisa dikuasai. Semakin sering siswa melakukan latihan praktik dasardasar elektronika otomotif yang dipelajarinya, maka akan semakin dapat menguasai kompetensi yang dipelajari tersebut. Pembelajaran praktik merupakan suatu proses untuk meningkatkan keterampilan siswa dengan menggunakan berbagai metode yang sesuai dengan keterampilan yang diberikan dan peralatan yang digunakan (Moeheriono, 2010). Selain itu, pembelajaran praktik merupakan suatu proses pendidikan yang berfungsi membimbing siswa secara sistematis dan terarah untuk dapat melakukan suatu ketrampilan.

Kemampuan praktik atau psikomotor siswa dilandasi oleh penguasaan teori atau kognitif sebagai kemampuan awal (Arifin, 2012). Ada empat modus belajar yaitu: concrete experience (pengalaman nyata), reflective observation (merefleksikan observasi), abstract conceptualization (konsep yang abstrak), dan active experimentation (eksperimen aktif). Efektifnya pembelajaran praktik tergantung pada bagaimana siswa melakukan refleksi dengan mengkaitkan antara pengetahuan dan pengalaman serta praktik. Waktu merupakan sesuatu yang mempengaruhi praktik siswa untuk mencapai KKM. Waktu yang dimaksudkan dalam hal ini adalah waktu yang digunakan untuk praktik dalam mencapai suatu tujuan pembelajaran. Mengingat bahwa waktu praktik sebagai salah satu faktor yang sangat penting untuk meningkatkan kemampuan siswa dan pencapaian prestasi siswa secara optimal, maka perlu dibuat suatu perencanaan yang baik dalam hal waktu belajar tersebut.

\section{METODE PENELITIAN}

Metode penelitian yang digunakan adalah kuasi eksperimen. Metode penelitian ini digunakan untuk mencari pengaruh perlakuan tertentu terhadap yang lain dalam kondisi yang terkendalikan. Metode kuasi eksperimen yang digunakan mengunakan pre-eksperimental design, karena dalam penelitian ini hanya mengunakan satu kelas yaitu kelas eksperimen tanpa adanya kelas kontrol. Instrumen yang digunakan adalah tes dan observasi, karena teknik pengumpulan data dalam penelitian ini yaitu tes pengguasaan teori (kognitif-afektif), tes unjuk kerja dan lembar observasi.

\section{HASIL PENELITIAN}

Hasil penelitian akan dijabarkan mengenai pengguasaan teori (kognitif-afektif) dan waktu latihan praktik siswa untuk mencapai standar KKM. 
Tabel 1. Rata-rata pengguasaan teori dan jumlah waktu praktik

\begin{tabular}{cccccc}
\hline \multirow{2}{*}{ Responden } & \multirow{2}{*}{ Kognitif-Afektif } & \multicolumn{4}{c}{ Waktu Praktik (menit) } \\
& & Latihan 1 & Latihan 2 & Latihan 3 & Total \\
\hline 30 & 89 & 37 & 19 & 12 & 68 \\
\hline
\end{tabular}

Waktu latihan praktik Dasar-dasar elektronika otomotif (Tabel 1) yang diperlukan untuk mencapai KKM diambil dari rata-rata waktu latihan pertama, kedua dan ketiga, yaitu 37 $+19+12=68$ menit. Waktu tersebut adalah waktu ideal setiap siswa melakukan latihan praktik untuk dapat mencapai standar waktu KKM. Perhitungan uji-r (korelasi) antara pengguasaan teori dengan jumlah waktu praktik. Berdasarkan hasil uji korelasi, nilai $r$ hitungnya adalah -0.679. Nilai tersebut mengambarkan bahwa koefisien korelasinya menunjukan hubungan tinggi atau kuat dengan arah negatif (berbanding terbalik). Siswa yang memiliki pengguasaan teori (kognitif-afektif) diatas KKM memerlukan jumlah waktu latihan (psikomotor) lebih cepat dibandingkan dengan siswa yang memiliki pengguasaan teori standar KKM. Maka hasil perhitungan uji korelasi pengguasaan teori (kognitif-afektif) dengan jumlah waktu praktik (psikomotor) didapatkan, penolakan $\mathrm{H}_{0}$ dan $\mathrm{H}_{\mathrm{a}}$ diterima yaitu terdapat hubungan yang signifikan antara jumlah waktu praktik (psikomotor) dengan pengguasaan teori (kognitif-afektif).

\section{PEMBAHASAN}

Berdasarkan waktu rata-rata dan jumlah latihan praktik dalam penelitian ini menunjukan bahwa jumlah waktu latihan praktik berbanding lurus dalam mencapai waktu standar KKM. Hasilnya adalah $\mathrm{H}_{\mathrm{a}}$ diterima, yaitu keperluan jumlah waktu praktik dasar-dasar elektronika otomotif untuk mencapai standar waktu KKM. Faktor yang mempengaruhi ketercapaian KKM salah satunya adalah jumlah waktu latihan praktik. Semakin banyak mengulang-ulang, keterampilan semakin bisa dikuasai. Semakin sering siswa melakukan latihan praktik dasar-dasar elektronika otomotif yang dipelajarinya, maka akan semakin dapat menguasai kompetensi yang dipelajari tersebut. Salah satunya saat siswa melakukan praktik pada latihan pertama, semakin banyak siswa mengulangi langkah kerja, maka langkah kerjanya menjadi makin dikuasai dan semakin mahir, serta waktu yang ditetapkan untuk praktik tersebut dapat tercapai dengan baik.

Waktu yang diperlukan oleh siswa pada latihan pertama jauh lebih lama untuk mengerjakan empat jobsheet, yaitu rangkaian transistor, resistor, dioda dan kapasitor. Namun 
pada latihan kedua dan latihan ketiga, waktu siswa untuk mengerjakan keempat jobsheet dasar-dasar elektronika otomotif tersebut lebih singkat. Faktor-yang menyebabkan waktu siswa menjadi lama yaitu kecakapan kognitif-afektif. Kecakapan aspek kognitif-afektif atau pemahaman teori kompetensi dasar-dasar elektronika otomotif yang dimiliki oleh siswa mempengaruhi aspek psikomotor dalam keterampilan melakukan praktik merangkai rangkaian. Hal tersebut dapat dilihat dari pengujian korelasi yang dilakukan antara pengguasaan teori (kognitif-afektif) dengan jumlah waktu praktik (psikomotor) yang menunjukan hubungan kuat atau tinggi. Hubungan kuat yang dihasilkan berbanding terbalik, dimana siswa yang memiliki pengguasaan teori (kognitif-afektif) diatas KKM pada saat melakukan praktik merangkai rangkaian dasar-dasar elektronika otomotif tidak memerlukan waktu latihan terlalu lama dibanding siswa yang memiliki nilai pengguasaan teori standar KKM. Siswa tersebut sudah memiliki informasi tentang komponen-komponen yang terdapat pada komponen dasar-dasar elektronika otomotif dan fungsi dari setiap komponen tersebut dalam rangkaian. Begitu juga sebaliknya, siswa yang melakukan praktik dasar-dasar elektronika otomotif dengan waktu lama disebabkan karena pengguasan teori standar KKM.

Kemampuan yang muncul pada diri siswa seperti kemampuan berpraktik, tentunya tidak akan muncul begitu saja tanpa adanya penguasaan siswa terhadap teori yang didapat saat belajar Hadisuwono. (2007). Terdapatnya hubungan yang signifikan dan positif antara tingkat penguasaan teori dengan kemampuan praktik, dimana kemampuan belajar praktik ditentukan oleh kemampuan awal yang mendasar yaitu kemampuan pemahaman secara teoritis.

Pengguasaan teori (kognitif-afektif) sangat mempengaruhi jumlah waktu praktik (psikomotor) yang dapat dilihat pada tabel dua di atas. Responden delapan dan 30 mendapatkan nilai ujian teori aspek kognitif standar KKM, yaitu 76. jumlah waktu praktik yang dibutukan responden delapan dan 30 paling lama dibandingkan dengan responden lainnya. Hasil ujian kognitif-afektif akan memberikan gambaran tingkat pengguasaan siswa terhadap teori kompetensi dasar-dasar elektronika otomotif (Syaodih, 2002). Siswa yang tingkat pengguasaannya tinggi membutuhkan waktu yang tidak terlalu lama dalam mempraktikkan empat jobsheet, yaitu rangkaian transistor, resistor, dioda dan kapasitor. Begitu juga sebaliknya, siswa yang tingkat pengguasaan teorinya masih lemah membutuhkan waktu yang cukup lama untuk mengerjakan jobsheet-jobsheet tersebut.

Berdasarkan uraian di atas dan hasil penelitian yang dilakukan, ternyata terdapat hubungan jumlah waktu praktik dengan ketercapaian KKM pembelajaran dasar-dasar elektronika otomotif siswa kelas X tahun ajaran 2013/2014 di SMK Negeri 6 Bandung. Selain 
itu juga, pengguasaan teori (kognitif-afektif) mempengaruhi waktu latihan praktik (psikomotor) siswa untuk mengerjakan jobsheet-jobsheet yang ada. Hal tersebut dapat menjadi tolak ukur keberhasilan pencapaian KKM Kompetensi dasar-dasar elektronika otomotif.

\section{KESIMPULAN}

Kesimpulan penelitian ini yaitu jumlah waktu praktik dasar-dasar elektronika otomotif yang ideal untuk mencapai standar waktu KKM adalah 15 menit tiga kali latihan praktik dengan total waktu 68 menit, dimana pencapaian standar waktu KKM berbanding lurus dengan jumlah waktu latihan praktik. Hubungan antara pengguasaan teori dan waktu praktik menunjukkan hubungan tinggi dan berbanding lurus. Siswa yang memiliki pengguasaan teori di atas KKM memerlukan jumlah waktu praktik lebih cepat dibandingkan dengan siswa yang nilai pengguasaan teori standar KKM.

\section{DAFTAR PUSTAKA}

Arifin, Z. (2012). Evaluasi Pembelajaran. Bandung: Remaja Rosdakarya.

Moeheriono. (2010). Pengukuran Kinerja Berbasis Kompetensi. Bogor: Ghalia Indonesia.

Sa’ud, U. S. (2009). Inovasi Pendidikan. Bandung: Alfabeta.

Sudarmanto. (2009). Kinerja dan Pengembangan Kompetensi SDM. Yogyakarta: Pustaka Pelajar.

Syaodih, N. (2002). Pengembangan Kurikulum: Teori dan Praktek. Bandung: PT. Remaja Rosdakarya.

Uno, H.B. (2012). Model Pembelajaran. Jakarta: Bumi Aksara.

Departemen Pendidikan Nasional. (2008). Pengembangan Perangkat Penilaian Psikomotor. Jakarta: Depdiknas.

Hadisuwono. (2007). Pentingnya Praktik di Kelas dan Refleksi dalam Pelatihan Guru. [online]. Tesedia: http://hadisuwono.blogspot.com/2007/01/pentingnya-praktik-dikelas-dan.html [16 Desember 2013]. 